\title{
COMMENTARIES
}

\section{The state of the unions.}

\section{Herbert Roth*}

"Man was born free, yet everywhere lives in chains" - this is the well-known opening sentence of Rousseau's Social contract. Trade unions in New Zealand present us with a similar paradox, though unfortunately I lack Rousseau's ability to express this in a dramatic form suitable for dictionaries of quotations. The paradox is that trade unions are among the most unpopular institutions in New Zealand, yet the number of unionists keeps increasing. This is by no means due entirely to compulsion : voluntary unions, such as the Public Service Association, have grown at a faster rate than unions where membership is compulsory, and new unions have been formed voluntarily by people in previously unorganised occupations, such as production supervisors, technicians and professional engineers. There was even a union of sauna and massage employees in the late 1970s but it collapsed, perhaps because the members did not wish to be covered by awards and preferred the bare minimum.

You will not disagree, I am sure, that unions have a very bad image in New Zealand. This can be documented from public opinion surveys, but I prefer to quote to you what Tom Scott had to say in the Listener a few years back, when he wrote that in terms of community status, New Zealand unionists "rank just behind traffic officers and a little ahead of child molesters."

Why then are unions growing in strength?

The simple explanation is that they fill a definite need in our economic set-up. Experience has shown that workers who loudly oppose unions and never attend a meeting, will rush into the secretary's office when they have trouble with their employer. People who condemn other workers for always being on strike, will readily stop work themselves when their economic interests are affected. And it is quite possible that some of the people who joined Auckland's well-publicised Kiwis Care march last year to protest against the Mangere airport strikers, had themselves taken part in the bank officers' strike a fortnight earlier. What is more, they probably were not aware of any contradiction in these two activities.

There are of course writers, especially in the letter columns of the daily press, who claim that there is no longer any place for trade unions or for industrial conflict in our society, that unions were needed a hundred or more years ago, when employers ground the faces of the poor, but not in today's enlightened welfare state. Curiously, the same was said a hundred and more years ago. In 1863, for instance, when the young Canterbury settlement experienced its first strike, the Press voiced its concern that there should commence "in this favoured settlement that odious struggle between the claims of labour and the rights of capital which has brought so much misery upon the labouring men of England". Workers, wrote the Press, "have well been called the industrial army: and the

* Text of lecture presented on 8 June 1982 as part of the Friends of the Turnbull Library's Winter Lecture series, "Towards Maturity". The editors are grateful to the Friends of the Turnbull Library for permission to publish the lecture. Readers interested in purchasing copies of the full set of lectures should see the advertisement on the page facing. 
simile holds good in this, that there must be officers to guide as well as men to do. The modern social system is so arranged that the officers in the industrial army are those who possess the capital".

Again, in 1876, when Auckland unionists set up a local trades council, the Daily Southern Cross warned against what it called "the tyranny of labour", which was likely to frighten capital. At that time the Auckland Trades Council had a total membership of a mere 158 workers, while today it comprises more than 110000 unionists. It seems that the right time for trade unions is always in the past but never today, just as with professional economists the right time for wage increases is always in the future but never in the present.

This year, as you know, we celebrated the centenary of the first shipment of refrigerated produce to London. This profoundly influenced our economic history by paving the way for New Zealand's transformation into Britain's cow yard and wool shed. As background to the problems facing New Zealand trade unions, I would like to make some comparisons between unionism today and a hundred years ago.

First of all, numbers. There are no official statistics of union membership in the $1880 \mathrm{~s}$, but I estimate that in 1880/1 there were about 40 unions operating in New Zealand, with an average membership of 25 , giving a total membership of about 1000 . In 1980, by comparison, and these are the latest official figures available, there were 516297 members of registered industrial unions of workers. If we add unions operating outside the Industrial Relations Act, mostly in the public sector, whose combined membership is about 170000 , we get a total union strength of almost 700000 . This is near 70 percent of all wage and salary earners.

The trade union movement has not only grown tremendously in numbers - in quantity over the last century, from 1000 to more than 700000 , but there has also been a very significant qualitative change. In $1880 / 1$ the thousand or so union members were male, white, and predominantly skilled, and their unions were confined virtually to the four main centres of population, without any national links. Let us look at these features in some detail :

Women today comprise more than a third of the total workforce, and their share of union membership, as far as one can tell, is of the same proportion. They are certainly underrepresented at the top of the union structure, as elected officials, secretaries, organisers or conference delegates, but there has been a noticeable trend towards greater participation by women in union affairs, particularly in recent years. This acceptance of women's equality has been by no means easy.

More than a hundred years ago, in February 1875, the Auckland Evening Star announced that it had engaged three young girls - the oldest was only 13 - to work in its printery. "They receive the same wages as other apprentices", said the paper, "and it is our resolution that for the same work they shall receive the same wages as men, when they have learned the business". The printers' union, the Auckland Typographical Society, was appalled. They did not object to their ages, for there were many young boys in printing offices, but to their sex. At a specially called union meeting, speakers claimed that in America female compositors were prostitutes and that "immorality must necessarily result from opening the printing trade to women". A deputation went to see the Star's editor; they admitted that there was nothing in their society's rules to prevent the employment of women, but they claimed that if women were admitted "it would interfere with their business and with their rights as men". When the Star refused to dismiss the girls, the union declared the printing office black.

Another example, much nearer in time : during the depression of the 1930 s women, for the first time, were offered employment in the engineering industry. Of course, the employers were looking for cheap labour, for female wages were only a fraction of adult male rates, but the Engineers' Union objected on principle to the employment of women. A resolution by its Dunedin branch described female labour in the industry as "a blot on a decent community", uncivilised and un-British.

The Tramways Union during the last war insisted that women trammies must be paid 
the same rates as men. This was a major breakthrough in the long campaign for equal pay, but the war was hardly over when the union suggested that the women should now resign. "I am sure our women comrades will be only too happy and willing to make way for our menfolk when the time arrives", wrote the union secretary in November 1945. Just to make sure, the union pressed the employers not to accept any further applications from women.

Finally, less than three years ago, Mrs Anne Barry had to take her fight all the way to the Human Rights Commission before she gained acceptance for training as a firefighter. Among her opponents was not only the employer, the Fire Services Commission, but also the Southern Fire Brigades Union which voted against the admission of women to the fire service. Fortunately by now union opinion was enlightened enough to give Mrs Barry overwhelming support; the Northern Fire Brigades Union backed her and so did the Federation of Labour.

I mentioned that union members in 1880 were all white. New Zealand workers today are certainly not free of racist prejudices, but the trade unions are playing a major part in supporting campaigns for racial equality and opposing apartheid. Such an attitude was not self-evident a hundred years ago; like support for female equality, it took a long time to gain acceptance. The vicious anti-Chinese prejudice which pervaded New Zealand has been well documented. Rather than traverse this ground, I would like to give you some examples of union attitudes towards another coloured minority, the Indians.

In 1910 the Seamen's Union conducted a campaign over the so-called Lascar Question, i.e. the employment of coloured seamen on ships trading to this part of the world. White Britishers, wrote the secretary of the Dunedin Seamen's Union, would be replaced by this alien element to the detriment of white women and white children. He stressed what he called "the moral aspect of the question", and he urged the Government to exclude these undesirables, maintain a white nation, and prevent the deterioration of New Zealand by intermingling with inferior races.

The Wellington Waterside Workers' Union, in 1916, decided not to accept Hindus as members. When the Railways Dept. in 1920 allegedly proposed to employ an Indian porter at Balclutha, the local branch of the Amalgamated Society of Railway Servants requested the general secretary to interview the Minister urgently, as the men refused to work with coloured labour. The general manager confirmed that it was not the policy of the department to employ Hindus. It is worth recalling that another ASRS branch, at Rangataua near Ohakune, took an entirely different view : it sent a remit to the 1920 conference deprecating hostility to fellow workers from Asia and opposing any movement that created antagonism between workers of different coloured skins as "our interests are identical, our only enemy being the capitalist class of all nations". This remit however was rejected at the ASRS national conference.

As late as 1942, Auckland drivers opposed the granting of a taxi licence to an Indian and refused to take him into their company. They submitted evidence from the principals of three girls' schools who did not wish to see Indians in the taxi service because, they said, Oriental viewpoints and standards were different - another hint at the threat of moral degradation of clean-living kiwis.

By contrast, I have not found any evidence of union hostility towards Maori workers. The trade union link with Maoris is almost a hundred years old, for in 1887 the Amalgamated Shearers' Union published a translation of its rules into Maori and enrolled Maori shearers on the East Coast of the North Island. Nobody keeps statistics of the proportion of Maori union members, but anybody who watches a union demonstration, march or picket, particularly in Auckland, will be struck by the large number of Polynesian faces. As is the case with women, Maoris are still underrepresented at the official level, but here too the trend is towards greater involvement.

I mentioned that unionists a century ago were skilled workers. They were tradesmen such as carpenters, engineers, printers, and tailors - these were the strongest - as well as bakers, butchers, bricklayers, bootmakers, painters, plasterers, stonemasons and shipwrights. The carpenters and engineers operated as branches of large British unions, but the 
others functioned independently as small societies in the main centres. The only unions outside Auckland, Wellington, Christchurch and Dunedin, which I have been able to trace in 1880/1 were tailors' societies in Timaru and Oamaru, and branches of the carpenters' society in Napier, Ashburton, Timaru, Oamaru and Invercargill. The first attempts at national organisation were made in 1881 , by tailors and printers, and at the local level a Trades Council was formed in Auckland in 1876, as mentioned earlier, and in Dunedin in 1881. There was no central union organisation; today of course we have national organisations in just about every occupation, local district trades councils or committees in 23 centres, and at the top of the union structure the N.Z. Federation of Labour with a membership approaching half a million workers.

The odd man out in 1880 among all the tiny craft societies was the N.Z. Seamen's Union, founded that year with the help of organisers sent from Melbourne. This was not a local union confined to skilled workers; it sought to operate as a national organisation and as a true industrial union whose doors were open to all men aboard ship regardless of skills, whether seamen or officers, carpenters, cooks or firemen. It didn't quite work out that way; the officers soon formed their own union and so did the marine engineers and the cooks and stewards, but the seamen's union was the harbinger of things to come. For most of the past century the large unions of unskilled and semi-skilled workers - seamen, miners, watersiders, and freezing workers - have been in the van of the New Zealand union movement. Skilled workers, who were the pioneers of unionism, took a back seat, but recent years have seen a revival of rank-and-file activity in skilled unions, which are gaining industrial muscle thanks to economic changes.

An entirely new development is white-collar unionism, which was unknown a century ago. White-collar workers - a term which covers professionals, administrative and managerial staff, clerical workers, shop assistants, foremen and other supervisors - now make up half the number of wage and salary earners. Until quite recently, to the extent that they were members of unions, they could best be described as apathetic and disgruntled, but today they are very "gruntled" indeed. Most of the new unions being formed are for white-collar workers, many of them have joined the Federation of Labour, and their industrial behaviour is now barely distinguishable from that of manual workers. They strike, go slow, hold stopwork meetings, picket, demonstrate, or simply withhold their goodwill. Even the oldest professions have caught the bug of industrial militancy : house surgeons have announced their intention to go slow, and the Minister of Justice had occasion last year to reprove the Law Society, when it threatened to withdraw duty solicitors unless their rates of pay were increased.

There is one other important difference between unions today and a hundred years ago; in the 1880s, the Government did not interfere in union affairs or in industrial relations generally. The only protective labour law on the statute book was an Employment of Females Act, which sought to restrict the hours of work of women and children, but it was not properly policed and therefore widely ignored. There was also a Trade Union Act, of 1878 , which gave legal recognition to unions, but few unions bothered to register under it.

The Government took no notice until the upsurge of unionism and industrial conflict which culminated in the Maritime Strike of 1890. After the defeat of the strike, Pember Reeves, the Minister of Labour in the new Liberal administration, introduced an Industrial Conciliation and Arbitration Act, which was passed in 1894. This act dominated New Zealand industrial relations for almost three-quarters of a century. It marked a radical departure from the traditional method of settling industrial disputes, by direct negotiations between the two parties immediately concerned, employers on one side, workers and their unions on the other. In its place we now had a three-sided system, with the third party, which represented the State, appearing in the guise of a conciliator or a judge of the Arbitration Court. This third party was not only present at every stage, it also had the final say.

At first arbitration was merely an option available to unions. They did not have to register under the Act and they did not have to use its procedures to settle their disputes 
with the employers. Indeed, some well-established unions ignored the Act as long as they could. Other workers however saw the new Arbitration Act as a great boon, for it forced employers who had previously refused to recognise unions, to come to the negotiating table. In occupations where unionism had collapsed after the Maritime Strike, particularly among unskilled workers, the Act made it possible to revive unions because it protected activists against victimisation.

What originally had been merely an option, quickly became the norm. Virtually every union in the private sector registered under the Arbitration Act and operated within its ambit. Unionism spread under the $A c t$ - the membership figures tell the story - but the post-1895 unions were very different from those which had preceded them. Many of them were artificial creations, formed to take advantage of the new legislation. Membership participation in such unions was minimal. The Court moreover increasingly interfered in the internal affairs of unions, especially where it granted preference of employment to union members. Their doors had to be open to all comers (the only nominal restriction referred to people not "of good moral character and sober habits"), entrance fees and subscriptions were subject to a low ceiling which kept unions poor, while the division of the country into eight industrial districts and the ban on amalgamations, except in so-called "related" industries, kept unions small. Even the aims and objects of registered unions were subject to the approval of the Labour Department's Registrar and had to be confined to "industrial matters", to the exclusion of politics. The result was a union movement which was fragmented, dependent and inefficient.

Overseas visitors commented on the peculiar nature of New Zealand trade unionism. Victor Clark, an American, described New Zealand unions in 1906 as "litigious rather than militant organisations, the creatures and instruments of State regulations". Ramsay Macdonald, the British labour leader who visited New Zealand, also in 1906, wrote that "a trades union in New Zealand exists mainly to get an award out of the Arbitration Court. The awards are given as a rule for two years, consequently there is no incentive for the workmen in that particular trade to do anything for at least two years. They cannot strike; it is no good their grumbling; they simply pay their dues into the union funds because they are legally bound to do it, and they take little interest in trades unionism as an industrial and political factor. One of the leading trades unionists of Wellington told me, 'Our laws have increased our size, but they have taken all the steel out of us' ".

Forty years later, when commenting on the impact of compulsory union membership, Anthony Hare wrote that union secretaries were invariably deteriorating into mere collectors of dues and that many members were indifferent or even hostile to unionism. There was an official in Dunedin at that time who was secretary of no fewer than 32 different unions; it was said that he arranged their meetings on the same night and if you were a quarter of an hour late, you were in the wrong meeting.

I can add to this from my own experience, for during the last war I worked for a year in Odlin's timber mill in Petone and became a member of the Wellington Timber Workers' Union. My contact with this union was minimal; I never saw a union representative, I never heard of any union meetings and I never received the union journal. My union dues were deducted from my wages by the company, and that was it.

Even more recently, around 1960, when I was asked to give a radio talk in a series on unionism, the producer stressed that I should try to explain the widespread apathy of union members and the lack of membership participation. These days nobody talks of union apathy and inactivity. On the contrary, many people feel that trade unions are too active today, and it is not far-fetched to link this change with the decline of the economy and of the compulsory arbitration system.

Despite frequent criticism and two major revolts, by the Red Feds in 1909-13 and by the watersiders and their allies in 1947-51, the compulsory arbitration system survived until the late 1960s. This requires some explanation, and I would put forward two major reasons for the success of arbitration, one ideological, the other economic.

When employers' and workers' representatives negotiate a new wage rate and settle on, say, 5 dollars an hour, there is nothing magical about this figure. It might have been higher 
or it might have been lower, depending on the amount of pressure each side was able to exercise and on the determination with which they pursued their claims, among other factors. Workers would regard it as the best they could achieve at this particular time, to be improved on at the first opportunity. However, when this same 5 dollar rate is set in an award of the Arbitration Court, it assumes an entirely different aspect. It now appears not as the compromise in a power struggle, but as the result of an impartial judicial investigation. Five dollars an hour is now justice, for a judge has declared it so. Anything more or less would be unjust.

A.K. Grant, in one of his humorous pieces in the Listener this year, imagined a Board of Air New Zealand (Restitution of Full Integrity) Bill, the purpose of which was to make the integrity of Air New Zealand board members a matter of law. The Arbitration Act had a similar purpose, for it made the determination of wage rates and working conditions a matter of law. Perceptive economists, like Professor Murphy at Victoria University College, might point out that the Arbitration Court "simply camouflages the underlying play of economic forces". A long-time member of the Arbitration Court, A.L. Monteith, might reveal that the Court "never awarded an increase in wages until and unless such increase was first won by militant unions on the industrial field". Nevertheless, the high regard for justice and law in our society ensured respect for decisions of the Arbitration Court, at least among the great majority of unionists, as long as these awards met their minimum expectations. Among the more notable doubters was F.P. Walsh, the strongman of the Federation of Labour. Asked at a union conference in 1962 whether workers could ever expect justice from the Arbitration Court, he replied : "Mr Duffy, you and I spring from the same race, and you know as well as I do the justice that was dealt out to our forefathers by the courts".

The second, and I think more important, reason for the long survival of the compulsory arbitration system was economic. Put simply, the Arbitration Court was respected as long as it was able to satisfy the majority of workers. Some observers - Colonel Weinstock in 1910, Professor Murphy in 1935 - claimed that while the economic situation was favourable, wages would have risen in any case, even without an Arbitration Court. There is evidence that the Court actually acted as a brake in times of prosperity, and that overall wage increases could have been higher without compulsory arbitration. This however is irrelevant. Most unionists believed that they owed their standard of living to the Arbitration Court and retained their faith in the arbitration system.

The Court moreover evened out the general trend, so that weak unions gained more than they could have achieved by their own efforts, while strong unions got less. The strong unions, those with economic muscle, were able to prove this on the occasions when they stepped outside the system and negotiated directly with their employers. These large militant unions regarded the arbitration procedures as straight-jacket - "Labour's leg-iron", to use Harry Holland's expression - but their efforts to bypass the system were defeated in 1913 and again in 1951. In both confrontations, the majority of unionists remained on the sidelines, while in 1951 some even supported the government against the watersiders. The turning point came in 1968, when the great majority of unionists lost their faith in the arbitration system. The immediate occasion was the Court's refusal to make a general wage order, which hit at the weak, inactive unions which rely on general orders to bring their wage level up to scratch.

"The Court of Arbitration was destroyed", wrote Mr Muldoon. He blamed the inexperience of the judge, but 1968 was merely the consummation of a process of growing disenchantment with compulsory arbitration which began in the early 1960s. The National Government's proposals to abolish compulsory union membership played a part in this. So also did the postwar growth of industries, which forced employers to compete for skilled labour and which pushed ruling rates way above the meagre rates awarded by the Court. We must also consider in this context Britain's entry into the Common Market, the consequent restrictions on New Zealand's exports to Britain and the economic dislocations this caused. The result was that by the end of the decade the Arbitration Court no longer satisfied the aspirations of New Zealand unionists. 
The Arbitration Court's jurisdiction was essentially over workers in secondary industries which produced for the domestic market and operated behind a wall of tariff protection. Workers in these industries benefitted from improved standards of living because their employers could pass on the cost in higher prices. Farm workers however remained outside the magic circle, because their employers produced for competitive world markets and could not pass on costs that exceeded their receipts.

While New Zealand prospered as Britain's dairy farm, and while our manufacturing industries remained small and directed towards the local market, the arbitration system prospered. When mother cut the apron strings, New Zealand had to fend for herself in a hostile world. Once the government started to dismantle import controls and protective tariff walls, the cosy traditional ways of preserving industrial peace no longer sufficed. A worldwide economic depression added to our problems and mounting inflation forced the government to intervene directly in the wage-fixing process, bypassing and, at times, overruling the Arbitration Court. There was not much pretence any longer that wages were set on an impartial, judicial basis; the process was seen as an economic and political power struggle, in which the government normally sided with the employer.

At the recent conference of Commonwealth heads of government in Melbourne the joke was current that Singapore was a south country which had moved north, while New Zealand was a north country moving south. In other words, they were moving towards the top bracket economically, the First World, while we were descending into the Third World. Some radical economists have even written about the inevitable "latinamericanisation" of New Zealand, a term coined to describe our future as a country with extremes of wealth and poverty and at the mercy of the multinationals, in short a banana republic. I don't feel qualified to comment on such forecasts, which are of course in sharp contradiction to our Government's view of the future. What is, I think, incontrovertible, is that we are in an economic crisis at present and that the immediate prospects are clouded.

The major problems facing workers and their unions today are inflation and unemployment. The Government is either unable or unwilling to halt the steady rise in prices. We have come to accept double-digit inflation as a way of life, and trade unions have no choice but to chase after double-digit wage rises in order to maintain their members' standard of living. They are forced to run fast in order to stand still, in order to preserve the status quo. We hear claims every so often that wages have gone ahead of price rises, but this usually takes no account of taxation, which increases as wage rises take workers into a higher income tax bracket. In any case, even if it is true that workers so far have been successful in keeping up with the cost of living, this only applies to those who have work. It certainly does not apply to those out of work whose numbers, according to a Press Association report, now include 2000 "hard-core unemployed" aged 16 years.

The immediate cause of unemployment is the deepening economic crisis throughout the Western World, and the Government's policies of restructuring and rationalisation of industries. This may be short-term phenomenon, if the depression passes at some point in the later 1980s, a mere "structural shakeout", to use economists' callous jargon. But there is also a second long-term cause of unemployment, and that is the introduction of new technology which irreversibly destroys jobs. These two factors moreover do not merely operate side by side, they also interact; during the economic depression of the 1930s the freezing companies replaced solo butchers by the chain system; today, in the depression of the 1980 s, the freezing companies are planning to replace meat workers by automatic pelting machines.

New technology has always replaced human labour. This is an ongoing process, but the current rate of technological advance is so rapid and revolutionary - and I am thinking in particular of silicon microchip technology - that it presents a threat to employment of quite unprecedented proportions. This has forced unions to think beyond their traditional area of wages, hours and conditions of work, and to look at the prospects of each industry and at the place of wage and salary earners in the society of the future.

There is growing evidence that the new technology will have a special impact on office work, through word processors, and on the retail trade, particularly supermarkets, through 
point-of-sale terminals. Both these occupations are predominantly female. The indications are that while new highly skilled jobs will be created for those who supervise and maintain the sophisticated equipment, many existing jobs will be deskilled and reduced to monotonous tasks. Like the manual worker on the shop floor, the white-collar worker of the future will be tied to a machine such as a computer terminal, which will closely monitor accuracy and speed of work, and thus strengthen managerial control.

Who will reap the benefit?

The first point to note is that unions do not oppose technological progress. They are not seeking to imitate the machine-breakers of early 19 th century England. They accept that the introduction of advanced technology is inevitable, indeed, that it can have positive results such as increasing productivity, raising living standards, making work easier and safer, and eliminating dirty, dangerous and repetitive jobs. What unions seek to achieve is to mitigate any adverse impact of technology on their members and to share in the benefits it can provide. In other words, they seek to humanise technology by bringing in considerations other than the rate of profit.

Unions therefore ask that when employers decide to introduce new technology, they should tell the people likely to be affected well in advance. This should be followed by negotiations between employers and unions on such questions as health and safety standards, retraining where required, payment for new skills and, if people's jobs are destroyed, their relocation within the firm or adequate compensation for redundancy. Several unions have already concluded agreements along these lines. The Bank Officers Union, in October last, decided, in a secret ballot to ban major changes or new methods or services unless the banks negotiated responsibly with the union.

One union approach which has caused much controversy lately, is to share the available work by reducing working hours and to share the benefits of increased productivity by not reducing wages.

This can be achieved in various ways; by reducing the weekly hours of work without reducing the weekly wage; or, by reducing the weeks of work by providing additional paid holidays; or, by reducing the years of work by allowing people to retire earlier on full superannuation. The unions argue that if all or some of these measures are adopted, the new technology need not lead to redundancies. Rather than work for some and unemployment for others, we could have some work for all, as well as more leisure and educational and recreational opportunities for all.

The employers and the Government argue that a shorter working week without reduced pay would mean a massive wage rise in disguise. This would be true without the safeguards which form part of the package put forward by the unions. These are restrictions on overtime and promises of increased productivity. The object, as the unions see it, is not to get extra pay but to preserve jobs. They do not want people to work 35 hours at ordinary rates and then do overtime at penal rates, but to work 35 hours and then stop, leaving the extra hours for somebody else. There will be problems in enforcing this, but the unions are anxious to co-operate in discouraging their members from working overtime. A steep increase in penal rates for overtime would induce employers to take on extra staff for extra work. Legal prohibitions could also be considered.

We have also been told that the country cannot afford a reduced working week, that prices would rise and businesses would face ruin. Any student of our industrial history must be cynical about these claims, because, for more than a century now, employers have opposed any reduction of working hours, whether for males or females, adults or children. New Zealand has successfully survived the 54-hour week and the 48-hour week, the 44 hour week and the 40-hour week, and I am confident that it will survive a further reduction of working hours. Other countries have; in Britain today about half the manual workforce, some 4 million people, have agreements for a working week of fewer than 40 hours, usually between 37 and 39 hours. They also enjoy longer annual holidays than we do. In Australia too, reduced working hours are spreading, despite opposition from Government and employers.

The first serious attempt to introduce a shorter working week with the consent of 
management was made last October in the freezing industry. New technology, such as the automatic pelting machine, is threatening to cut manning levels in this industry by up to 40 percent. To save jobs, the Meat Workers' Union put forward the concept of " 4 for 5 "; the same number of people, they claimed, working 4 days a week instead of 5 but using improved technology, could increase output by half. The management of the Longburn freezing works found this proposal attractive, because it would reduce the unit cost of processing. They opened negotiations with the union, but there was such an outcry from employers and farmers that the Government stepped in and vetoed the proposal.

The alternative of course is a growing number of redundancies in the freezing industry Southdown, Westfield, Gear Meat, Hellaby's and most recently Patea - a total of 3000 jobs lost in the past 20 months, while only 1000 jobs were created at new works at Oringi and Takapau. Frustrated in their efforts to save jobs, the unions are reduced to seek monetary compensation, redundancy payments, for the workers laid-off.

Britain has had a Redundancy Payments Act since 1965; it now forms part of a comprehensive Employment Protection Act. Payments are made by the firm which discharged the employee, but it can recover half the amount from a central fund administered by the government and financed by a levy on employers. The size of the payments depends on the wage, age and length of service of the employee. The philosophy behind this law was explained by the president of the Industrial Appeals Tribunal : "A redundancy payment is compensation for loss of a right which a long-term employee has in his job. Just as a property owner has a right to his property and when he is deprived he is entitled to compensation, so a long-term employee is considered to have a right to security". The British Employment Protection Act also requires employers to give prior notification of impending redundancies and to consult with unions on how to avoid redundancies.

New Zealand made a half hearted attempt to regulate redundancies with a Severance and Re-employment Bill which was introduced in 1975, but lapsed the following session with the change of government. Several subsequent attempts to regulate redundancy payments have been defeated in Parliament. Since there is no law in New Zealand which gives workers the right to compensation for loss of employment, unions have had to fight for it. And I say "fight" advisedly, because there have been numerous confrontations over this issue, such as the Rixen sit-in at the end of last year, and the national freezing workers' strike this March. The Government's only contribution has been a threat to limit the size of redundancy payments in order to avoid, as the Minister of Labour put it, a situation where greed replaced need. We have however a generous redundancy scheme for members of Parliament, financed by a compulsory levy on the employers - you and me.

The main victims of the depression so far have been the unemployed. Wage and salary earners have, more or less, held their own, but they now face a sustained attack designed to convince public opinion, and union members themselves, that unions are to blame for the country's economic ills, that unions are selfish and are responsible for unemployment. The Government's and the employers' plans to revive the economy and to restore profits are based on the premise that the living standards of wage and salary earners must be reduced.

New Zealand workers even now have one of the lowest wage levels among developed countries. Nevertheless, according to the Minister of Trade and Industry, wage and salary earners have to spearhead the attack on inflation. In other words, workers are asked to surrender hard-won conditions and to tighten their belts. Already several groups, such as Air New Zealand employees, Wellington rubbish collectors, local body officers and Ocean Beach freezing workers have been forced to accept significant cuts in their income.

The outlines of this attack on living standards are clearly visible. Employers' spokesmen complain that they have to carry "social burdens", such as equal pay for women workers, accident compensation, and maternity leave. They want to reduce wage rates for young people, and the Government has promised to meet this demand. The Government is also reducing the workers' "social wage" by cutting health, education and welfare services.

The employers demand more discipline in what they call "a sloppy society". Their aim is to turn the clock back in industrial relations, to end free wage bargaining, which to them is "the law of the jungle", and to return to compulsory arbitration, coupled with strict 
penalties for strikes and other forms of industrial action. As a first step in this direction the Government last year put through legislation designed to restrict free bargaining by giving the Minister of Labour powers to refer disputes in key industries to the Arbitration Court for compulsory settlement.

The Government has now gone further and has threatened to abolish free wage bargaining altogether and to introduce wage controls. It hopes, by this means, to achieve "responsible wage settlements", meaning single-digit wage rises while prices continue to rise at double-digits. The main obstacle to this policy of shifting the burden of the depression on to the shoulders of wage and salary earners is the strength of the trade union movement.

Wellingtonians last February must have watched with amazement when Mr Neary, of the Electrical Workers Union, pinned a Polish "Solidarity" badge on Mr Muldoon's lapel. Does our Prime Minister really support a union, which has been among the most strikeprone in history, which campaigned strongly for a shorter working week, and which demanded the right of union members to elect factory managers and company executives?

Whatever Mr Muldoon supports in Poland, Solidarity's aims are not Government policy in New Zealand. On the contrary, our Government is eager to reduce and restrict the power of the unions. It has gone back on its election policy on union amalgamation and now threatens to split and fragment the union movement by sponsoring separate unions in each plant. This would give us not a few hundred unions, as at present, but thousands of weak, ineffective organisations. These would be, to coin a phrase, the unions you have when you don't have a union. The persistent attempts to divide the union movement politically, the claims that the unions are dominated by the Socialist Unity Party, the personal attacks on Mr Knox and the denunciations of foreign-born unionists are all part of this campaign. It has already succeeded in frightening some Labour politicians who are now scurrying for cover, denying the very people who brought their party into being, fed it and reared it.

I don't want to leave you with the impression that I think unions are perfect, or that I approve of everything unions do. By no means! I mentioned earlier in this talk how difficult it was for unionists to accept women and racial minorities as equals. I told you of my own very negative experiences with unionism some forty years ago. There are still today unions with minimal rank-and-file participation, undemocratic unions, unions where women are not welcome, and so on. But with all their shortcomings, warts, abscesses and other deformities, unions remain the worker's best friend.

Ever new generations are learning this truth through their own experiences : the young clothing workers at the Rixen factory in Levin who probably never gave unions a thought until they were thrown out of work; the courageous freezing workers at Oringi who had to overcome tremendous odds before they could set up a branch of the Meat Workers Union; and the teenage paper boys and girls who came to the Federation of Labour here in Wellington to ask for help in getting better pay and conditions.

We can imagine a just society in which the good of the community is paramount, but in our present economic system the profit motive prevails and self-interest rules. Nobody should blame unions if they pursue their own self-interest and band together to maintain and improve their members' standard of living. 